\title{
Using Electronic Media and the Problem of Prophetic Communication Behavior at UIN Syarif Hidayatullah Jakarta
}

\author{
Ade Abdul Hak \\ Department of Library Information Science \\ Syarif Hidayatullah State Islamic University Jakarta \\ Indonesia \\ ade71@uinjkt.ac.id \\ Tine Silvana Rachmawati \\ Department of Communication Science \\ Universitas Padjadjaran \\ Bandung, Indonesia \\ tine.silvanadunpad.ac.id
}

\author{
Agus Rusmana \\ Department of Library and Information Science \\ Univesitas Padjadjaran \\ Bandung, Indonesia \\ a.rusmana@unpad.ac.id \\ Asep Saeful Muhtadi
Department of Communication and Islamic Dakwah Universitas Islam Negeri Sunan Gunung Djati
Bandung, Indonesia
samuh@uinsgd.ac.id

\begin{abstract}
Humanization, liberation, and transcendence communication as prophetic communication behavior becomes a crucial part for the free use of electronic media. An aspect often overlooked with this freedom is the ethics of communication. A case sample occurring in the community is easily the spreading of untrue stories or hoax. No exception, it also happens in Islamic universities. For this reason, the purpose of this study was to investigate the effects of media literacy and information behavior to prophetic communication behavior for the lecturers of Syarif Hidayatullah State Islamic University Jakarta. A questioner survey based on a stratified random sample of $\mathbf{1 0 0}$ lecturers at $\mathbf{1 1}$ faculties had been taken for this explanatory research. Data analyzed by SPSS 22 indicated that all questioner items were valid and reliable. The results showed that there were significant relationships between the media literacy, information behavior, and prophetic communication behavior: humanization, liberation, and transcendence. Simultaneously, the effects of information behavior and media literacy to the prophetic communication behavior are significant. T-Test analysis indicated that there was positive and significant effect for the information behavior, but not for the media literacy. Meanwhile, the most occurred in the effect of information behavior to the humanization communication with effect value of $64 \%$. The value of study proves that it becomes important for lecturers to get the media literacy. Although it is partially no significant, the media literacy influences on the information behavior significantly. The prophetic communication behavior, as social ethical cognition to communicate in electronic media, will have a high value if the information behavior is high.
\end{abstract}

Keywords - media literacy; information behavior; prophetic communication behavior; uses and gratifications.

\section{INTRODUCTION}

Going on the rapid development of information and communication technology, the creation and dissemination of information based on text, audio, or audiovisual are increasingly easy to do. As a part of the development, such activity is a form of freedom in the use of communication media. As a result, many aspects change in the communication order. Audiences are no longer merely an object of information exposure, but have been more actively involved as well as producers of the information itself [1], [2]. On one side, this freedom of media makes the audiences more independently get the rights to the information needed. But on the other side, this freedom can also bring the audiences to have immoral behavior. One of the examples is the case of easy spreading of untrue stories or hoax in the community. No exception, it also happens in Islamic universities or other public universities. In this case, the position of Syarif Hidayatullah State Islamic University Jakarta has a significant role, especially in providing cases for other universities and the social in order to use communication media in accordance with the values that have been exemplified by Prophet Muhammad SAW as prophetic ethics in communication.

For this reason, the research objective is to investigate how the prophetic communication behavior is significantly influenced by the media literacy and information behavior both partially and simultaneously. The advantage of this study is practically to describe the important of the media literacy and information behavior of the lecturers and to know their effects to the prophetic communication behavior at UIN Syarif Hidayatullah Jakarta; also to recommend the importance of teaching the media literacy.

\section{CONCEPT AND THEORY}

Sunnah Rasulullah as prophetic ethics in presenting the 
value of the Qur'an in the dynamic social construction has been successfully described by Kuntowijoyo in the prophetic social science [3]. The basis of his philosophy is embodied in the concept of amar ma'ruf nahi munkar, as the word of Allah SWT in the letter of Al-Imran verse 110: 'You are the best nation [ever] brought fort for mankind: you bid what is right and forbid what is wrong, and have faith in Allah'.

Furthermore, according to Kuntowijoyo, Muktiyo, argued that the religious ethical values of the verse are closed to prophetic communication, because the value in the Qur'an and Sunnah is derived through the prophetic spirit. So, it can be said to have the same slice. In addition, prophetic communication is not just a matter of dakwah, but it's a broad humanitarian issue; wherein it contains oriented communication in amar ma'ruf (humanization), nahi munkar (liberation), and tu'minu billahi (transcendence) [4].

One of the ways applying the process of humanization, liberation, and transcendence in the context of communication is by looking at the connection of the communication context with the mass media. The values contained in the verse are not anti to technology, industry, and modernization. However, they are anti in contradiction of all the oppression, the destruction of human dignity, and all sorts of things that break away from the rest of transcendence [5].

The statement describes that the prophetic values can be used as the basis of ethics when someone is using and spreading the message based on information technology. In addition, the values will guide him to receive the messages. This linkage will unify prophetic values in the use of information technology that must make his spirit in the communication process....... in order not to cause unrest.

In this context, it is necessary to empower the community by using electronic communication media. Communities play a major role in the communication process, so they need to be prepared by teaching media literacy including selfunderstanding and reflection. Having the media literacy, they will be able to choose, understand, question, evaluate, shape and or create, and respond deeply to the media of communication in accordance with the moral values that exist in the community [5].

Meanwhile, the electronic media usage can be the information seeking behavior, that is the purposive seeking for information as a consequence of a need to satisfy some goals; the information use behavior consists of the physical and mental acts involved in incorporating the information found into the person's existing knowledge base [6].

In fact, the information seeking and information use behavior are triggered first by one's understanding of the pressures and problems in his life. Pressures and problems in life are what motivate a person to use the media [6]. It is referred to as the information searching behavior. Wilson explained that the whole of human behavior relating to sources and channels of information, including information seeking and information use behavior both actively and passively is an information behavior [7].

One of the theories to study the use of communication media is Uses and Gratifications Theory. The core of theory is the audiences are basically using mass media by certain motives. Media is considered to try to meet the audiences' motif. If the motive is fulfilled, then the needs of the audiences will be fulfilled. In the end, the media which are capable of meeting the needs of the audiences is called effective media [8], [9], [10], [11].

This theory also describes how the internal and environmental factors will affect the motives for using media to be chosen. In this regard Katz and Gurevitch explained that the human needs are influenced by social environment, group affiliation, and personality traits. Hence, the creation of needs relates to the media includes cognitive, affective, integrative personality, integrative social and the need for releasing [8], [12].

Previously, the studies illustrated by Akser [13] and Saidu [14] had the importance of responsibility values for optimizing the role of technology and networks as a medium of communication. Similarly, case studies conducted by O'Neil [15] and Ahmad at all. [16] illustrated how actually communication media became an essential tool of movement among combatants; and became a significant tool for demonstrators to exchange information and send their message to the outside world in encouraging the public to rise against the political downturn.

Leung showed that there was a significant relationship between internet connectivity with information literacy and a strong relationship between information literacy and quality of life [17]. These findings encourage that the use of communication media has a positive impact on the quality of life of a person as long as the media is used with good intentions [8], [18]-[20].

The early studies showed how Uses and Gratifications theory is used to study the advantage of communication media. Unfortunately, some of these studies have not yet been fully explored to illustrate how the influence of selfcompetence (media literacy) and motives influence the usage of media (information usage behavior) on the prophetic communication behavior model.

Researches on the topic of prophetic communication had been only done by some UIN Yogyakarta students. Suryani conducted research on "Nilai profetik dalam Media Massa (Analisis Isi Opini Harian Republika Periode Ramadhan 1434 H)", Prophetic Value on Mass Media (Analyzing Republika Content of the Ramadhan $1434 \mathrm{H}$ ) by producing three elements of prophetic communication: humanization in the form of 'choice title' and 'diction'; liberation in the form of 'author opinion', 'opinion content', 'opinion theme', and 'opinion target'; and transcendence of linear 'values' or 'messages' with the Qur'an and Hadith [21]. Furthermore, Dani conducted research on prophetic communication with the title of "An Application of Prophetic Communication at Pondok Pesantren" with the aim at knowing how the process of encoding and decoding done by students in applying and building the prophetic values interpersonally and transcendental in boarding school environment [22]. 


\section{METHOD}

The primary data of the research were 100 questionnaires of the lecturers at 11 faculties at Syarif Hidayatullah State Islamic University Jakarta. The sample was selected by stratified random sampling technique with the aim of making homogeneous properties of the population considered heterogeneous [9], [23]. The sample size was obtained by Taro Yamane formula of known population size [24], 1004 lecturers with $10 \%$ precision and $95 \%$ confidence level.

The validation test of the questionnaire showed that all items of question had sig. value. 0.000 (smaller than) $<\alpha=$ 0.05 , and the lowest of r-,test 0.329 is above r-table 0.197 . It means that the instrument is valid. Likewise, the results of reliability test showed the value of Cronbach's Alpha 0.739 (greater than) $>0.6$, it means that the instrument is reliable.

\section{RESULT AND DISCUSSION}

Based on descriptive analysis, the view of the media literacy of lectures at Syarif Hidayatullah State Islamic University Jakarta showed the average of 3.7 in the range of scale 1-5. It means that the competence of media literacy is very high. This is like the description of the information use behavior (4.09), humanization-prophetic communication behavior (4.2), liberation-prophetic communication behavior (4.22), and transcendent-prophetic communication behavior (4.18). The numbers are certainly not without reason. Based on demographic data, $73 \%$ of the lecturers have experienced more than 4 years of internet access and $72 \%$ have received media usage training. In addition, almost $70 \%$ have educational backgrounds in Islamic colleges.

Furthermore, the hypothesis testing based on the research design had three structural equation models: 1) $\mathrm{Y} 1=p y_{1} z+$ $\left.\left.p y_{1} x+p y_{1} \square_{1} ; 2\right) \mathrm{Y} 2=p y_{2} z+p y_{2} x+p y_{2} \square_{2} ; 3\right) \mathrm{Y} 3=p y_{3} z+$ $p y_{3} x$

$+p y_{3} \square$ 3. as illustrated in the following figure 1 . The results can be concluded that there were significant relationships between the information behavior (X), media literacy (Z), and prophetic communication behavior (Y): humanization (Y1), liberation (Y2), and transcendent (Y3).

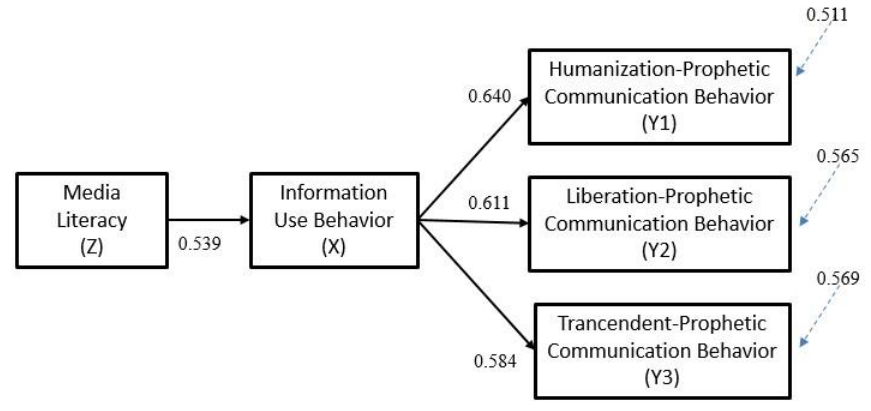

Fig. 1 Causal Effect of the Media Literacy and Information Behavior to the Prophetic Communication Behavior

There is positive and strong link between these variables, significant value $(0.000)<\alpha=0.05$; each variable had an effect to the others as standardized coefficient value. For example, the effect of the media literacy to information behavior was significant, 0.000 (0.539). It means that any value added on the variable of media literacy, then the communication behavior will increase by $53 \%$. Simultaneously, media literacy and information use behavior influence the humanization-prophetic communication behavior (0.489); the balance was 0.511 from others not participated in this model. This rate, principally, applied equally to other variables because they had the same significant levels and influence relationships as depicted in the figure.

The research findings showed that the media literacy measured by lecturer's information behavior had a positive and significantly influence on the high or low of the lecturer's information behavior. It means that the high or low of the behavior was explained by the literacy. Therefore, to optimize the information behavior, there should be an attempt to increase the media literacy. It provided opportunities for the lecturer to have more motivation and responsible to meet their information needs by using electronic media.

The self-actualization of information needs is reflected in the behavior of the use of electronic media as well as communication behavior. It describes how the internal factors (cognitive, affective, integrative personality, integrative social and the need for releasing) affect the motives for communicating in electronic media. In this case, the information use behavior of the lecturers made continued behavior in using electronic media to communicate religiously. With being motivated and responsible to meet their information needs, the lecturers used the electronic media to elevate the human identical (humanization), emancipate human beings from freedom of expression (liberation), and appeal people closer to God (transcendent) as prophetic communication behavior.

The finding in the study is in accordance with some former findings viewed by Hobbs $(2015,6)$ that scholars working from within the media effects paradigm had also made considerable progress in exploring how media literacy might mitigate the negative impact of media messages on attitudes and behavior [25]. Then, the media literacy will make a crucial part for the lecturers in participating the electronic media freedom as a basic competency of prophetic communication behavior.

\section{CONCLUSION}

It is verified that the freedom of the use of electronic media will affect the prophetic communication behavior by having media literacy on behaving the information. Scientifically, using a questioner measuring of the effect of media literacy and information behavior to prophetic communication behavior provides a framework to investigate the relationship of the variables in confirming the concept of prophetic communication behavior as a part of communication theory. It is suggested to make a deeply interviewed study to intensify the framework of prophetic communication behavior in using electronic media. 


\section{REFERENCES}

[1] P. Dimaggio, E. Hargittai, W. R. Neuman, and J. P. Robinson, "Social Implications of the Internet," Annual Review of Sociology, vol. 27, no. 2001, pp. 307-336, 2016.

[2] R. Nasrullah, Teori dan Riset Media Siber (Cybermedia), Cet. 2. Jakarta: Prenadamedia Group, 2016.

[3] Kuntowijoyo, Islam sebagai ilmu: epistemologi, metodologi, dan etika, Ed. 2. Bandung: Tiara Wacana, 2007.

[4] W. Muktiyo, "Etika religius dalam komunikasi," 2011. [Online]. Available: http:/2011/05/10/etika-religius- dalam-komunikasi/. [Accessed: 01-Jun-2016].

[5] I. Syahputra, Komunikasi Profetik: Konsep dan Pendekatan. Yogyakarta: Simbiosa Rekatama Media, 2007.

[6] T. D. Wilson, "Human Information Behavior," Informing Science, vol. 3, no. 2, 2000.

[7] D. O. Case, Looking for Information: A Survey of Research on Information Seeking, Needs, and Behavior. San Diego: Academics Press, 2002.

[8] B. Aljenaibi, "Digital Media Platforms and Education: The Uses of Social Networking in the UAE and China," Journal of Media Critiques, vol. 1, no. 1, 2015.

[9] R. Krisyanto, Teknik praktis riset komunikasi: Disertai contoh riset media, public relation, advertising, komunikasi organisasi, komunikasi pemasaran, Cet. 7. Jakarta: Kencana Prenada Media Group, 2014.

[10] A. Kunandar, "Model Literasi Media pada Anak dalam Mencegah Konflik Sosial," Profetik: Jurnal Komunikasi, vol. 7, no. 1, pp. 87-99, Apr. 2014.

[11] P. Purnawarman, S. Susilawati, and W. Sundayana, "The use of Edmodo in teaching writing in a blended learning setting," Indonesian Journal of Applied Linguistics, vol. V, no. 2, 2016.

[12] V. Balakrishnan and H.-S. Loo, "Mobile Phone and Short Message Service Appropriation , Usage and Behavioral Issues among University Students," Journal of Social Sciences, vol. 8, no. 3, pp. 364-371, 2012.

[13] M. Akser, "Technology and the Turkish Mind: Internet Animation as Counter Culture in Turkey," CINEJ Cinema Journal, vol. 3, no. 2, p. 192, Oct. 2014.

[14] B. Saidu, "Rethinking 'Freedom of Information' for a New Era of Transparency in Public Service Media in Nigeria," Medijske studije, vol. 5, no. 10, pp. 124-137, 2014.

[15] P. H. O'Neill, "Why the Syrian uprising is the first social media war," The Daily Dot, 2013. [Online]. Available: http://www.dailydot.com/layer8/syria-civil- social-media-waryoutube/. [Accessed: 26-Oct-2016].

[16] A. Ahmad, A. R. Ahmad, and N. H. H. H. Hamasaeed, "The Role of Social Media in the "Syrian Uprising," Journal of Economic Development, Environment and People, vol. 4, no. 2, pp. 39-48, 2015.

[17] L. Leung, "Effects of Internet Connectedness and Information Literacy on Quality of Life," Source: Social Indicators Research Soc Indie Res, vol. 98, no. 2, pp. 273-290, 2010.

[18] S. N. Gifary and I. Kurnia, "Intensitas Penggunaan Smartphone Terhadap Perilaku Komunikasi,” Jurnal Sosioteknologi, vol. 14, no. 2, pp. 170-178, 2014.

[19] B. Ogwo, "E-literacy Skills and Programme Improvement in the Informal Sector Market/Mechanic Village Schools in South eastern Nigeria', in NORRAG NEWS, Towards a New Global World of Skills Development? TVET's turn to Make its Mark," 2011. [Online]. Available: http://www.norrag.org. [Accessed: 03-Dec2016].

[20] T. Seechaliao, "Lecturers' Behaviors And Beliefs About The Use Of Social Media In Higher Education : A Study At Mahasarakham," vol. 10, no. 2, pp. 155-160, 2014.

[21] I. Suryani, "Nilai profetik dalam Media Massa (Analisis Isi Opini Harian Republika Periode Ramadhan 1434 H)," UIN Sunan Kali Jaga Yogyakarta, 2014.

[22] U. Dani, "Aplikasi komunikasi profetik di pondok pesantren (Studi deskriptif komunikasi profetik pada santri mahasiswa di pondok pesantren Sulaemaniayah Yogyakarta)," UIN Yogyakarta, 2015.

[23] W. G. Cochran, Sampling Techniques, Ed. 3. New York: Jhon Wiley \& Son, 1977.

[24] Riduwan and E. A. Kuncoro, Cara Mudah Menggunakan dan Memaknai Path Analysis (Analisis Jalur) Lengkap dengan Contoh Tesis dan Perhitungann SPSS 17.0, Cet. 3. Bandung: Alfabeta, 2011.

[25] R. Hobbs, "Media Literacy," Oxford Research Encyclopedia of Communication, 2015. 